\title{
Selected parameters of water quality of the swimming pools port in Szczecin
}

\section{Wybrane parametry jakości wód w basenach portowych w Szczecinie}

\author{
Piotr Daniszewski ${ }^{1}$, Beata Draszawka - Bołzan ${ }^{2}$ \\ ${ }^{1}$ Katedra Zoologii Bezkręgowców i Limnologii, Uniwersytet Szczeciński \\ ul. Wąska 13, 71-415 Szczecin, Poland, \\ ${ }^{2}$ Katedra Chemii i Ochrony Środowiska Wodnego, Wydział Biologii, Uniwersytet Szczeciński, \\ ul. Felczaka 3C, 71-412 Szczecin, Poland \\ E-mail address: daniszewski@univ.szczecin.pl
}

\begin{abstract}
To estimate differentiation of water chemistry in reservoirs of swimming pools port in Szczecin, in time of 2004 - 2008. In arbitrary appointed times 5 physical and chemical indicators of water quality were determined to evaluate general status and water condition - temperature, $\mathrm{pH}, \mathrm{COD}-\mathrm{Cr}$, $\mathrm{BOD}_{5}, \mathrm{Cl}^{-}$.
\end{abstract}

Keywords:

swimming pools port; natural water quality; temperature; $\mathrm{pH}$; $\mathrm{COD}-\mathrm{Cr} ; \mathrm{BOD}_{5} ; \mathrm{Cl}^{-}$

\section{STRESZCZENIE}

Celem niniejszej pracy było prześledzenie w okresie od 2004 do 2008 roku poziomu oraz dynamiki zmian w wodach basenów portowych Portu Szczecin parametrów ogólnych jakości wód. W pracy oznaczano wskaźniki ogólne wody: temperaturę, $\mathrm{pH}$, ChZT-Cr, $\mathrm{BZT}_{5}, \mathrm{Cl}^{-}$. Wszystkie oznaczenia i obliczenia wykonywano według metod zalecanych przez Polskie Normy, stosując procedury analityczne opisane m.in. przez Dojlido, Elbanowska, Hermanowicza.

\section{Stowa kluczowe:}

baseny portowe, jakość wód, temperatura, $\mathrm{pH}, \mathrm{ChZT}-\mathrm{Cr}, \mathrm{BZT}_{5}, \mathrm{Cl}^{-}$.

\section{WPROWADZENIE}

Akweny wodne są $\mathrm{w}$ Polsce cennym elementem środowiska przyrodniczego i powinny być objęte ochroną [1,3,5-9]. Akweny wodne pełnią m.in. rolę: hydrologiczną, mikroklimatyczną, hydrosanitarną, przemysłową [1,2,7-10,12,14,16,18,19]. Zgodnie z Ramową Dyrektywą Wodną, do 2015 r. wszystkie wody, w tym również w akwenach portowych, powinny mieć dobry stan ekologiczny $[1,3,6-9,12,15,16,9]$.

Baseny portowe należą do akwenów, których wody są szczególnie narażone na zanieczyszczenia $\mathrm{w}$ związku z przeładunkami jakie maja miejsce na ich terenie $[11,13,20$, 21, 24-26]. Podstawową funkcją Portu Szczecin jest import zboża, rud, olejów, papieru, 
celulozy, bloków granitowych, drobnicy oraz eksport węgla, żelaza, zboża, drobnicy [20, 21, 24-29]. Baseny portowe w Szczecinie zlokalizowane są w estuarium Odry. Estuarium Odry cechuje się znaczą zmiennością warunków hydrologicznych, co również wpływa na stan jakości wód basenów portowych usytuowanych na terenie miasta Szczecina [20-23, 25].

W latach 2004 - 2008 przeprowadzono badania jakości wód portowych w 10 basenach portowych Portu Szczecin - Górniczy, Kaszubski, Warty, Notecki, Mieleński, Parnica, Wschodni, Zachodni, Kanał Dębicki, Warsztatowy. W pobranych próbach wody oznaczano 5 wskaźników jakości wód, które charakteryzują stan jakości wód naturalnych.

\section{CZĘŚĆ DOŚWIADCZALNA}

Badania zostały przeprowadzone na terenie 10 basenów portowych Portu Szczecin w miesiącach czerwiec - wrzesień 2004 - 2008. Port Szczecin jest położony w zachodniej części woj. zachodniopomorskiego, w środkowej części Szczecina, w dzielnicy Śródmieście [25-29].

Znajduje się w odległości ok. $69 \mathrm{~km}$ na południe od Zatoki Pomorskiej ok. $11 \mathrm{~km}$ od Zalewu Szczecińskiego [25-29]. Na mapie nr 1 i 2 przedstawiono usytuowanie Portu w Szczecinie.

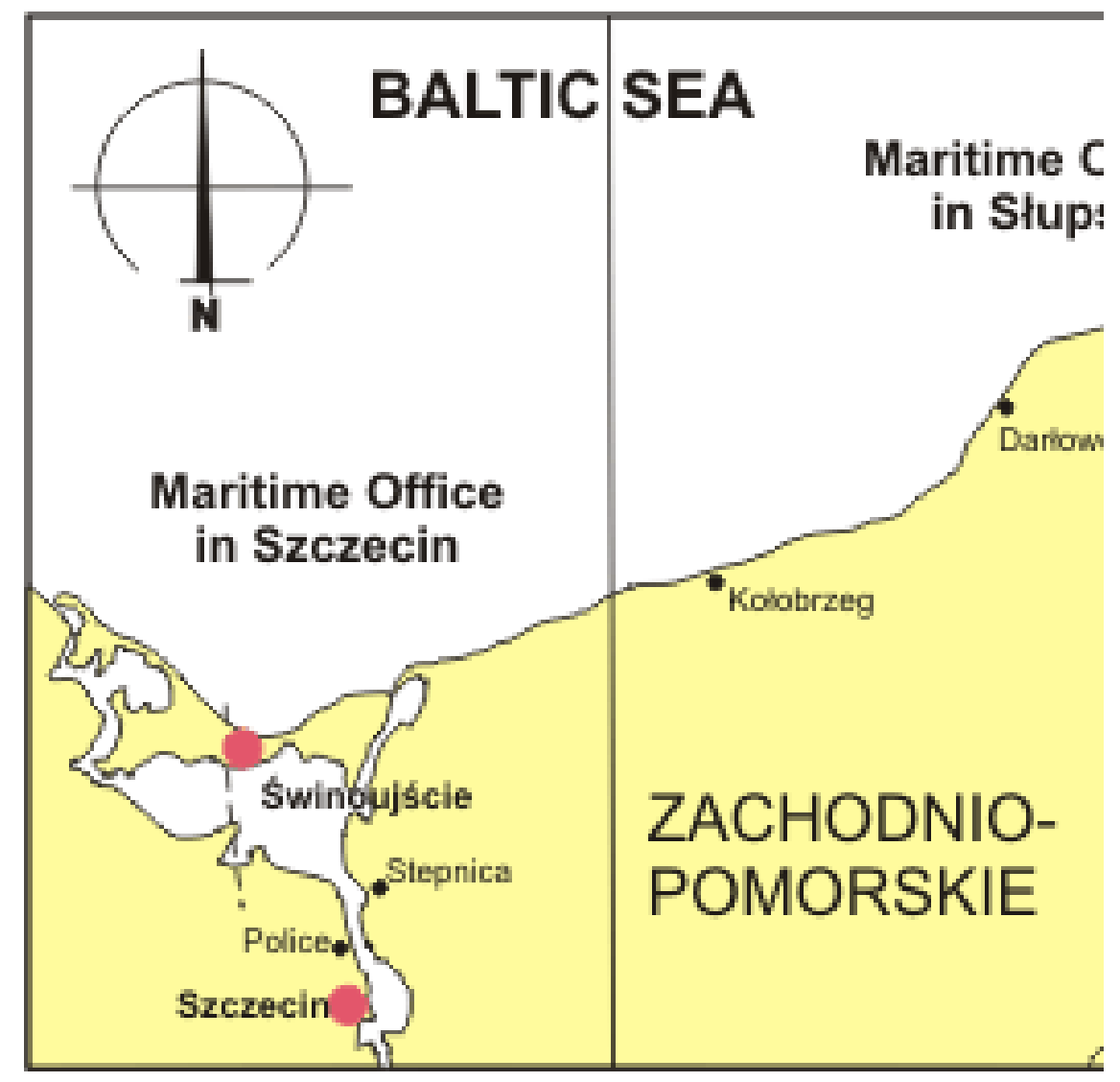

Mapa 1. Usytuowanie Portu w Szczecinie [27-28]. 


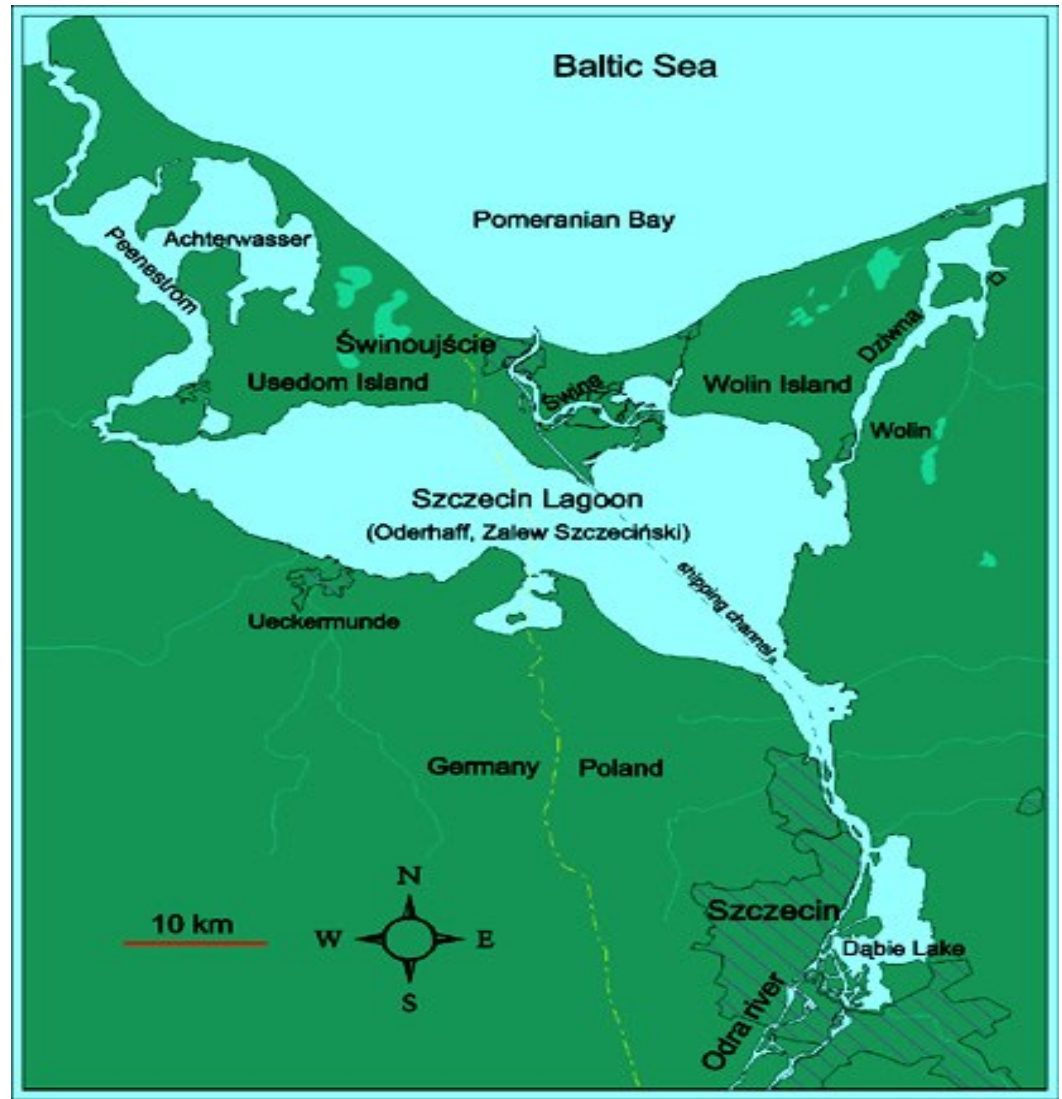

Mapa 2. Usytuowanie Portu w Szczecinie [27-28].

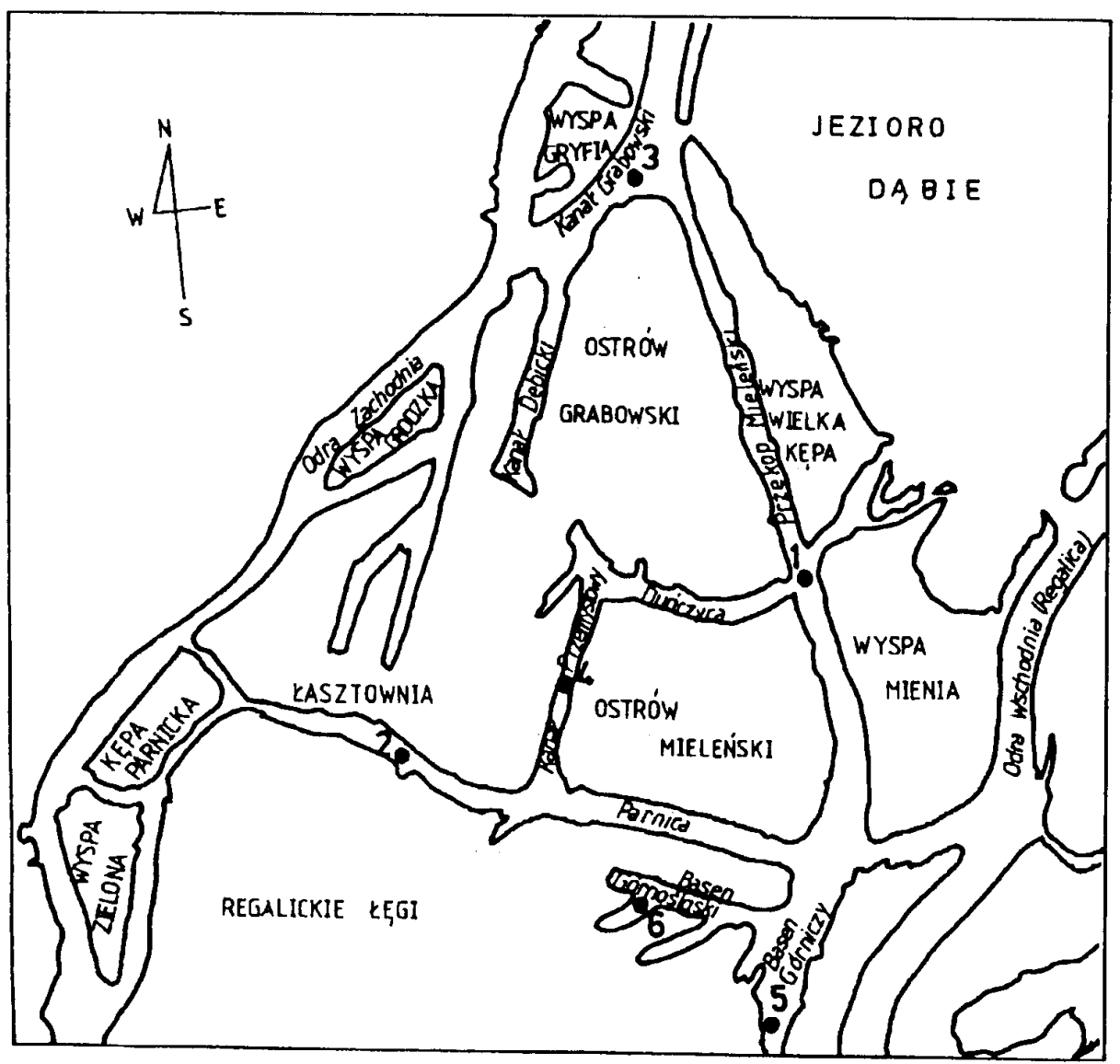

Rys 1. Mapa kanałów i basenów Portu w Szczecinie [27-28] 
Port Szczecin jest usytuowany na Odrze i jej prawym ramieniu Regalicy. Położony jest w zachodniej części Pobrzeża Szczecińskiego, w północnej części Doliny Dolnej Odry na Międzyodrzu [27-29]. W skład portu wchodzą akweny będące odgałęzieniami Odry i kanałami: Przekop Mieleński, Kanał Grabowski, Duńczyca, Kanał Wrocławski, Parnica, Kanał Dębicki oraz jezioro Dąbie [27-29]. Na rysunku nr 1 przedstawiona została mapa kanałów i basenów Portu w Szczecinie.

Port Szczecin ma 103 nazwane nabrzeża, są to: Huty, Cementowe, Fosforowe, Południowe, Fosforowe Dalby, Snop, Bunkrowe, Huk, Żeglugowy Basen, Hydrograficzne, BTP, BON, Mak, Jachtowy Basen, Golęcińskie, Oko, Oko Basen, Cal, Drab II, Młyński Basen, Drab III, Warsztatowy Basen, Warsztatowe, Promowy Basen, Wulkan, Drzetowskie Północne, Drzetowskie Południowe, Odra Stare, Odra Nowe, Wrocławskie, Warszawskie, Radomskie, Kieleckie, Gdyńskie, Gdańskie, Przydekowe, Kaszubskie, Łańcuchowe, Mazowieckie, Wyposażeniowe, Gnieźnieńskie, Krakowskie, Arsenał, Kapitanatu, Pasażerskie, Bulwar Chrobrego, Wieleckie, Starówka, Bułgarskie, Tureckie, Rosyjskie, Kubańskie, Jugosłowiańskie, Albańskie, Greckie, Egipskie, Rumuńskie, Węgierskie, Polskie, Angielskie, Belgijskie, Holenderskie, Luksemburskie, Zbożowe, Niemieckie, Słowackie, Czeskie, Spółdzielcze, Fińskie, Ciche, PRCiP, Przemysłowe, Farblak, Remontowe, PRO, Nowe, Elektrowni, CPN-3, Parnickie, Naftowe, CPN-1, Sosnowieckie, Kokschemii, Opolskie, Dolnośląskie, Noteckie, Gorzowskie, Drawskie, Górnośląskie, Poznańskie, Toruńskie, Bydgoskie, Rybnickie, Wałbrzyskie, Czołowe, Pirs, Bytomskie, Południowe, Gliwickie, Chorzowskie, Katowickie, Zabrzańskie, Dąbrowieckie [27-29].

Próby wody do badań pobierano według PN/C-04632.03 z głębokości ok. 0,5 m poniżej lustra wody. W miejscu poboru prób oznaczano temperaturę, $\mathrm{pH}$. Pobrane próbki wody zostały utrwalane zgodnie z zaleceniami zawartymi w Polskiej Normie - PN/C04632.04. Pozostałe wskaźniki określające jakość wód zostały oznaczone w przeciągu 24 godzin od momentu pobrania prób.

Oznaczenie ilości rozpuszczonej materii organicznej podatnej na utlenienie określano jako ChZT zgodnie z PN/C-04578.02, stężenie chlorków - oznaczano zgodnie z PN/C-04617.02. Poszczególne wskaźników jakości wód oceniano według kryteriów zalecanych do oceniania śródlądowych wód powierzchniowych określonych w Rozporządzeniu Ministra Środowiska z dnia 11 lutego 2004 r. w sprawie klasyfikacji dla prezentowania stanu wód powierzchniowych i podziemnych, sposobu prowadzenia monitoringu oraz sposobu interpretacji wyników i prezentacji stanu tych wód.

\section{DYSKUSJA WYNIKÓW I WNIOSKI}

Wyniki badań wskaźników jakości wód powierzchniowych basenów portowych Portu Szczecin za okres 2004 - 2008 wraz z klasyfikacją wartości badanych wskaźników wg kryteriów Rozporządzenia Ministra Środowiska z dnia 11 lutego 2004 r. przedstawiono w tabelach od 1 do 5 . 
Tabela 1. Wyniki badań wskaźników jakości wód powierzchniowych basenów portowych Portu Szczecin w 2004 roku wraz z klasyfikacją wartości badanych wskaźników wg kryteriów

Rozporządzenia Ministra Srodowiska z dnia 11 lutego 2004 r.

\begin{tabular}{|l|c|c|c|c|c|}
\hline \multirow{2}{*}{ Badany basen } & \multicolumn{5}{|c|}{ Wskaźnik jakości wód (jednostki) } \\
\cline { 2 - 6 } & $\begin{array}{c}\mathrm{pH} \\
(\mathrm{jedn} . \mathrm{pH})\end{array}$ & $\begin{array}{c}\text { Temperatura } \\
\text { wody }\left({ }^{\circ} \mathrm{C}\right)\end{array}$ & $\begin{array}{c}\mathrm{ChZT}-\mathrm{Cr} \\
\left(\mathrm{mg} \mathrm{O}_{2} \cdot \mathrm{dm}^{-3}\right)\end{array}$ & $\begin{array}{c}\mathrm{BZT}_{5} \\
\left(\mathrm{mg} \mathrm{O}_{2} \cdot \mathrm{dm}^{-3}\right)\end{array}$ & $\begin{array}{c}\mathrm{Cl}^{-} \\
\left(\mathrm{mg} \mathrm{Cl}^{-} \mathrm{dm}^{-3}\right)\end{array}$ \\
\hline Górniczy & $7,64(\mathrm{I})$ & $14,5(\mathrm{I})$ & $23(\mathrm{III})$ & $2,16(\mathrm{II})$ & $123(\mathrm{II})$ \\
\hline Kaszubski & $7,73(\mathrm{I})$ & $16,2(\mathrm{I})$ & $27(\mathrm{III})$ & $2,87(\mathrm{II})$ & $145(\mathrm{II})$ \\
\hline Warty & $7,81(\mathrm{I})$ & $15,7(\mathrm{I})$ & $21(\mathrm{III})$ & $2,10(\mathrm{II})$ & $239(\mathrm{III})$ \\
\hline Motecki & $7,92(\mathrm{I})$ & $16,5(\mathrm{I})$ & $17(\mathrm{II})$ & $2,78(\mathrm{II})$ & $176(\mathrm{II})$ \\
\hline Parnica & $8,02(\mathrm{I})$ & $14,9(\mathrm{I})$ & $16(\mathrm{II})$ & $3,25(\mathrm{III})$ & $142(\mathrm{II})$ \\
\hline Zachóski & $7,93(\mathrm{I})$ & $15,4(\mathrm{I})$ & $20(\mathrm{II})$ & $3,07(\mathrm{III})$ & $185(\mathrm{II})$ \\
\hline Kanał Dębicki & $7,59(\mathrm{I})$ & $15,8(\mathrm{I})$ & $25(\mathrm{III})$ & $2,09(\mathrm{II})$ & $139(\mathrm{II})$ \\
\hline Warsztatowy & $7,82(\mathrm{I})$ & $16,1(\mathrm{I})$ & $24(\mathrm{III})$ & $3,12(\mathrm{III})$ & $173(\mathrm{II})$ \\
\hline
\end{tabular}

Objaśnienia: I, II, III - klasyfikacja wartości badanego wskaźnika wg kryteriów Rozporządzenia Ministra Środowiska z dnia 11 lutego 2004 r.

Tabela 2. Wyniki badań wskaźników jakości wód powierzchniowych basenów portowych Portu Szczecin w 2005 roku wraz z klasyfikacją wartości badanych wskaźników wg kryteriów

Rozporządzenia Ministra Srodowiska z dnia 11 lutego 2004 r.

\begin{tabular}{|l|c|c|c|c|c|}
\hline \multirow{2}{*}{ Badany basen } & \multicolumn{5}{|c|}{ Wskaźnik jakości wód (jednostki) } \\
\cline { 2 - 6 } & $\begin{array}{c}\mathrm{pH} \\
(\mathrm{jedn} . \mathrm{pH})\end{array}$ & $\begin{array}{c}\text { Temperatura } \\
\text { wody }\left({ }^{\circ} \mathrm{C}\right)\end{array}$ & $\begin{array}{c}\mathrm{ChZT}-\mathrm{Cr} \\
\left(\mathrm{mg} \mathrm{O}_{2} \cdot \mathrm{dm}^{-3}\right)\end{array}$ & $\begin{array}{c}\mathrm{BZT}_{5} \\
\left(\mathrm{mg} \mathrm{O}_{2} \cdot \mathrm{dm}^{-3}\right)\end{array}$ & $\begin{array}{c}\mathrm{Cl}^{-} \\
\left(\mathrm{mg} \mathrm{Cl}^{-3} \mathrm{dm}^{-3}\right)\end{array}$ \\
\hline Górniczy & $7,57(\mathrm{I})$ & $15,6(\mathrm{I})$ & $27(\mathrm{III})$ & $3,15(\mathrm{III})$ & $146(\mathrm{II})$ \\
\hline Kaszubski & $7,82(\mathrm{I})$ & $16,6(\mathrm{I})$ & $24(\mathrm{III})$ & $2,78(\mathrm{II})$ & $173(\mathrm{II})$ \\
\hline Warty & $7,87(\mathrm{I})$ & $14,7(\mathrm{I})$ & $22(\mathrm{III})$ & $3,26(\mathrm{III})$ & $152(\mathrm{II})$ \\
\hline Notecki & $7,72(\mathrm{I})$ & $16,1(\mathrm{I})$ & $21(\mathrm{III})$ & $2,83(\mathrm{II})$ & $218(\mathrm{III})$ \\
\hline Mieleński & $7,59(\mathrm{I})$ & $14,3(\mathrm{I})$ & $19(\mathrm{II})$ & $3,16(\mathrm{III})$ & $185(\mathrm{II})$ \\
\hline Parnica & $7,82(\mathrm{I})$ & $16,1(\mathrm{I})$ & $21(\mathrm{III})$ & $2,86(\mathrm{II})$ & $149(\mathrm{II})$ \\
\hline Zachodni & $7,76(\mathrm{I})$ & $14,3(\mathrm{I})$ & $25(\mathrm{III})$ & $3,09(\mathrm{III})$ & $238(\mathrm{III})$ \\
\hline Kanał Dębicki & $7,70(\mathrm{I})$ & $15,5(\mathrm{I})$ & $22(\mathrm{III})$ & $2,82(\mathrm{II})$ & $163(\mathrm{II})$ \\
\hline Warsztatowy & $7,74(\mathrm{I})$ & $15,7(\mathrm{I})$ & $26(\mathrm{III})$ & $3,19(\mathrm{III})$ & $205(\mathrm{III})$ \\
\hline
\end{tabular}

Objaśnienia: I, II, III - klasyfikacja wartości badanego wskaźnika wg kryteriów Rozporządzenia Ministra Środowiska z dnia 11 lutego 2004 r. 
Tabela 3. Wyniki badań wskaźników jakości wód powierzchniowych basenów portowych Portu Szczecin w 2006 roku wraz z klasyfikacją wartości badanych wskaźników wg kryteriów

Rozporządzenia Ministra Środowiska z dnia 11 lutego 2004 r.

\begin{tabular}{|l|c|c|c|c|c|}
\hline \multirow{2}{*}{ Badany basen } & \multicolumn{5}{|c|}{ Wskaźnik jakości wód (jednostki) } \\
\cline { 2 - 6 } & $\begin{array}{c}\mathrm{pH} \\
(\mathrm{jedn} . \mathrm{pH})\end{array}$ & $\begin{array}{c}\text { Temperatura } \\
\text { wody }\left({ }^{\circ} \mathrm{C}\right)\end{array}$ & $\begin{array}{c}\mathrm{ChZT}-\mathrm{Cr} \\
\left(\mathrm{mg} \mathrm{O}_{2} \cdot \mathrm{dm}^{-3}\right)\end{array}$ & $\begin{array}{c}\mathrm{BZT}_{5} \\
\left(\mathrm{mg} \mathrm{O}_{2} \cdot \mathrm{dm}^{-3}\right)\end{array}$ & $\begin{array}{c}\mathrm{Cl}^{-} \\
\left(\mathrm{mg} \mathrm{Cl}^{-} \mathrm{dm}^{-3}\right)\end{array}$ \\
\hline Górniczy & $7,73(\mathrm{I})$ & $15,8(\mathrm{I})$ & $24(\mathrm{III})$ & $3,56(\mathrm{III})$ & $236(\mathrm{III})$ \\
\hline Kaszubski & $7,62(\mathrm{I})$ & $15,1(\mathrm{I})$ & $21(\mathrm{III})$ & $2,74(\mathrm{II})$ & $272(\mathrm{III})$ \\
\hline Warty & $7,56(\mathrm{I})$ & $16,2(\mathrm{I})$ & $28(\mathrm{III})$ & $3,15(\mathrm{III})$ & $217(\mathrm{III})$ \\
\hline Motecki & $7,85(\mathrm{I})$ & $16,3(\mathrm{I})$ & $23(\mathrm{III})$ & $2,45(\mathrm{II})$ & $174(\mathrm{II})$ \\
\hline Parnica & $7,72(\mathrm{I})$ & $15,3(\mathrm{I})$ & $26(\mathrm{III})$ & $1,95(\mathrm{I})$ & $248(\mathrm{III})$ \\
\hline Wschodni & $7,63(\mathrm{I})$ & $15,1(\mathrm{I})$ & $24(\mathrm{III})$ & $2,38(\mathrm{II})$ & $153(\mathrm{II})$ \\
\hline Zachodni & $7,80(\mathrm{I})$ & $14,9(\mathrm{I})$ & $22(\mathrm{III})$ & $1,85(\mathrm{I})$ & $149(\mathrm{II})$ \\
\hline Kanal Dębicki & $7,74(\mathrm{I})$ & $14,2(\mathrm{I})$ & $24(\mathrm{III})$ & $2,19(\mathrm{II})$ & $252(\mathrm{III})$ \\
\hline Warsztatowy & $7,79(\mathrm{I})$ & $15,5(\mathrm{I})$ & $27(\mathrm{III})$ & $2,48(\mathrm{II})$ & $194(\mathrm{II})$ \\
\hline
\end{tabular}

Objaśnienia: I, II, III - klasyfikacja wartości badanego wskaźnika wg kryteriów Rozporządzenia Ministra Środowiska z dnia 11 lutego 2004 r.

Tabela 4. Wyniki badań wskaźników jakości wód powierzchniowych basenów portowych Portu Szczecin w 2007 roku wraz z klasyfikacją wartości badanych wskaźników wg kryteriów

Rozporządzenia Ministra Srodowiska z dnia 11 lutego 2004 r.

\begin{tabular}{|l|c|c|c|c|c|}
\hline \multirow{2}{*}{ Badany basen } & \multicolumn{5}{|c|}{ Wskaźnik jakości wód (jednostki) } \\
\cline { 2 - 6 } & $\begin{array}{c}\mathrm{pH} \\
(\mathrm{jedn} . \mathrm{pH})\end{array}$ & $\begin{array}{c}\text { Temperatura } \\
\text { wody }\left({ }^{\circ} \mathrm{C}\right)\end{array}$ & $\begin{array}{c}\mathrm{ChZT-Cr} \\
\left(\mathrm{mg} \mathrm{O}_{2} \cdot \mathrm{dm}^{-3}\right)\end{array}$ & $\begin{array}{c}\mathrm{BZT}_{5} \\
\left(\mathrm{mg} \mathrm{O}_{2} \cdot \mathrm{dm}^{-3}\right)\end{array}$ & $\begin{array}{c}\mathrm{Cl}^{-} \\
\left(\mathrm{mg} \mathrm{Cl}^{-} \mathrm{dm}^{-3}\right)\end{array}$ \\
\hline Górniczy & $7,45(\mathrm{I})$ & $15,1(\mathrm{I})$ & $23(\mathrm{III})$ & $2,83(\mathrm{II})$ & $187(\mathrm{II})$ \\
\hline Kaszubski & $7,36(\mathrm{I})$ & $15,2(\mathrm{I})$ & $28(\mathrm{III})$ & $3,15(\mathrm{III})$ & $153(\mathrm{II})$ \\
\hline Warty & $7,71(\mathrm{I})$ & $14,4(\mathrm{I})$ & $26(\mathrm{III})$ & $3,27(\mathrm{III})$ & $196(\mathrm{II})$ \\
\hline Notecki & $7,70(\mathrm{I})$ & $15,3(\mathrm{I})$ & $23(\mathrm{III})$ & $2,71(\mathrm{II})$ & $172(\mathrm{II})$ \\
\hline Parnica & $7,63(\mathrm{I})$ & $14,8(\mathrm{I})$ & $25(\mathrm{III})$ & $2,84(\mathrm{II})$ & $241(\mathrm{III})$ \\
\hline Wschodni & $7,80(\mathrm{I})$ & $15,3(\mathrm{I})$ & $23(\mathrm{III})$ & $2,40(\mathrm{II})$ & $219(\mathrm{III})$ \\
\hline Zachodni & $7,59(\mathrm{I})$ & $14,7(\mathrm{I})$ & $27(\mathrm{III})$ & $3,14(\mathrm{III})$ & $175(\mathrm{II})$ \\
\hline Wanał Dębicki & $7,49(\mathrm{I})$ & $15,1(\mathrm{I})$ & $26(\mathrm{III})$ & $2,84(\mathrm{II})$ & $237(\mathrm{III})$ \\
\hline
\end{tabular}

Objaśnienia: I, II, III - klasyfikacja wartości badanego wskaźnika wg kryteriów Rozporządzenia Ministra Środowiska z dnia 11 lutego 2004 r. 
Tabela 5. Wyniki badań wskaźników jakości wód powierzchniowych basenów portowych Portu Szczecin w 2008 roku wraz z klasyfikacją wartości badanych wskaźników wg kryteriów

Rozporządzenia Ministra Środowiska z dnia 11 lutego 2004 r.

\begin{tabular}{|l|c|c|c|c|c|}
\hline \multirow{2}{*}{ Badany basen } & \multicolumn{5}{|c|}{ Wská́nik jakości wód (jednostki) } \\
\cline { 2 - 6 } & $\begin{array}{c}\mathrm{pH} \\
\text { (jedn. } \mathrm{pH})\end{array}$ & $\begin{array}{c}\text { Temperatura } \\
\text { wody }\left({ }^{\circ} \mathrm{C}\right)\end{array}$ & $\begin{array}{c}\mathrm{ChZT}-\mathrm{Cr} \\
\left(\mathrm{mg} \mathrm{O}_{2} \cdot \mathrm{dm}^{-3}\right)\end{array}$ & $\begin{array}{c}\mathrm{BZT}_{5} \\
\left(\mathrm{mg} \mathrm{O}_{2} \cdot \mathrm{dm}^{-3}\right)\end{array}$ & $\begin{array}{c}\mathrm{Cl}^{-} \\
\left(\mathrm{mg} \mathrm{Cl}^{-} \mathrm{dm}^{-3}\right)\end{array}$ \\
\hline Górniczy & $7,42(\mathrm{I})$ & $14,6(\mathrm{I})$ & $22(\mathrm{III})$ & $2,63(\mathrm{II})$ & $160(\mathrm{II})$ \\
\hline Kaszubski & $7,76(\mathrm{I})$ & $15,3(\mathrm{I})$ & $26(\mathrm{III})$ & $2,85(\mathrm{II})$ & $183(\mathrm{II})$ \\
\hline Warty & $7,68(\mathrm{I})$ & $14,2(\mathrm{I})$ & $25(\mathrm{III})$ & $3,26(\mathrm{III})$ & $159(\mathrm{II})$ \\
\hline Notecki & $7,76(\mathrm{I})$ & $15,4(\mathrm{I})$ & $23(\mathrm{III})$ & $3,18(\mathrm{III})$ & $193(\mathrm{II})$ \\
\hline Mieleński & $7,69(\mathrm{I})$ & $14,8(\mathrm{I})$ & $22(\mathrm{III})$ & $2,79(\mathrm{II})$ & $210(\mathrm{III})$ \\
\hline Parnica & $7,80(\mathrm{I})$ & $15,2(\mathrm{I})$ & $28(\mathrm{III})$ & $2,64(\mathrm{II})$ & $185(\mathrm{II})$ \\
\hline Zachodni & $7,82(\mathrm{I})$ & $14,9(\mathrm{I})$ & $23(\mathrm{III})$ & $2,85(\mathrm{II})$ & $170(\mathrm{II})$ \\
\hline Kanał Dębicki & $7,78(\mathrm{I})$ & $15,1(\mathrm{I})$ & $25(\mathrm{III})$ & $2,83(\mathrm{II})$ & $237(\mathrm{III})$ \\
\hline Warsztatowy & $7,69(\mathrm{I})$ & $15,0(\mathrm{I})$ & $22(\mathrm{III})$ & $2,73(\mathrm{II})$ & $174(\mathrm{II})$ \\
\hline
\end{tabular}

Objaśnienia: I, II, III - klasyfikacja wartości badanego wskaźnika wg kryteriów Rozporządzenia Ministra Środowiska z dnia 11 lutego 2004 r.

Wody basenów portowych Portu Szczecin w okresie prowadzonych badań posiadały wartości $\mathrm{pH}$ zbliżone do obojętnego lub lekko zasadowego - w całym okresie badawczym zostały zaliczane do I klasa jakości wód wg kryteriów Rozporządzenia Ministra Środowiska z dnia 11 lutego $2004 \mathrm{r}$.

W ekosystemach wodnych badanych basenów badana wartość ChZT-Cr kształtowała się głównie na poziomie dla wód III klasy jakości. Wskaźniki mineralizacji wód badanego jeziora cechowały się ustabilizowanym stężeniem badanych makroskładników jonowych wody na poziomie II i III klasy jakości wód. W całym okresie badawczym tj. $2004-2008$ wody basenów portowych Portu Szczecin posiadały wskaźniki oceny jakości wód od I klasy do III klasy jakości.

$\mathrm{Z}$ uwagi na narażenie basenów portowych Portu Szczecin na zanieczyszczenia związane z przeładunkami jakie odbywają się na jego terenie zboża, rud, olejów, celulozy, drobnicy węgla, żelaza, należy prowadzić badania oceny jakości wód tych basenów, aby można na bieżąco ocenić stan wód tych akwenów.

\section{Podziękowania}

Autorzy artykulu pragna podziękować za możliwość przeprowadzenia badań na akwenach basenów portowych Portu Szczecin oraz udostepnienie wyników badań Laboratorium Badań Środowiska Pracy Zarządu Morskich Portów Szczecin i Świnoujście. 


\section{Polskie Normy}

PN/C-04540.03. Badania wartości pH, kwasowości i zasadowości. Oznaczanie kwasowości i zasadowości mineralnej i ogólnej metodą miareczkowania wobec wskaźników.

PN/C-04578.02. Badania zapotrzebowania tlenu i zawartości węgla organicznego. Oznaczanie chemicznego zapotrzebowania tlenu ChZT.

PN/C-04586.03. Oznaczanie żelaza ogólnego i rozpuszczonego w zakresie $0,02-10 \mathrm{mg} / \mathrm{dm}^{3}$ metodą kolorymetryczną z 1,10-fenantroliną lub 2,2'-dwupirydylem.

PN/C-04617.02. Oznaczanie chlorków w wodzie i ściekach metodą argentometrycznego miareczkowania.

PN/C-04632.03. Ogólne zasady pobierania próbek do badań fizycznych, chemicznych i biologicznych. Technika pobierania próbek.

PN/C-04632.04. Ogólne zasady pobierania próbek do badań fizycznych, chemicznych i biologicznych. Utrwalanie i przechowywanie próbek.

PN/C-06504. Przygotowanie roztworów buforowych.

\section{References}

[1] Barik S.K., Purushothaman C.S., Mohanty A.N., Aquacult. Res. 32 (2001) 819-832.

[2] Bowden K. F., Oceanic and Estuarine Mixing Processes. W: Riley J. P., Skirrow G. (eds.), Chemical Oceanography. London-New York-San Francisco 1974, 1-41.

[3] Buchholz W., Zmienność stanów i przepływów w ujściach rzek na przykładzie ujścia Odry. Materiały Sesji Naukowej KBM PAN. Szczecin 1990, 49-70.

[4] Buchholz W., Materiaty do monografii Dolnej Odry. Warunki hydrologicznohydrodynamiczne. Prace IBW PAN, Gdańsk, 22 (1990) 1-117.

[5] Daniszewski P., International Letters of Chemistry, Physics and Astronomy 1 (2012) 6-12.

[6] Daniszewski P., International Letters of Chemistry, Physics and Astronomy 1 (2012) 13-16.

[7] Daniszewski P., International Letters of Chemistry, Physics and Astronomy 2 (2012) 42-45.

[8] Daniszewski P., International Letters of Chemistry, Physics and Astronomy 2 (2012) 46-52.

[9] Daniszewski P., International Letters of Chemistry, Physics and Astronomy 2 (2012) 35-41.

[10] Demel K., Życie morza. Gdańsk 1974.

[11] Dojlido J.R., Chemia wód powierzchniowych, Wydawnictwo Ekonomia i Środowisko 1995.

[12] Druet C., Elementy hydrodynamiki geograficznej, Warszawa 1995.

[13] Elbanowska H., Zerbe J., Siepak J., Fizyczno-chemiczne badania wód. Wydawnictwo Naukowe PWN: 1999, ss. 232. 
[14] Grasshoff K., , Methods of Seawater Analysis. Weinheim-New York 1976.

[15] Hermanowicz W., Dojlido J., Dożańska W., Koziorowski B., Zerbe J., Fizyczno-chemiczne badanie wody $i$ ścieków, Arkady, Warszawa 1999.

[16] Jasińska E., , Dynamika słonych wód w estuariach polskich rzek. Inst. Budownictwa Wodnego PAN, 24 (1991) 1-206.

[17] Kajak Z., Hydrobiologia-Limnologia. Ekosystemy wód śródlądowych, PWN, Warszawa 1998, ss. 355.

[18] Leybovich S., Ulrich D., J. Geophys. Res. 77 (1972) 1683-1688.

[19] Lyman J., Chemical consideration, physical and chemical properties of sea water. Washington 1959, cited after: Monin A. S., (red.), Chimija okieana. T. 1, Chimija wod okieana. Moskwa 1979.

[20] Majewski A., (red.), Zalew Szczeciński. Warszawa 1980.

[21] Majewski A., Charakterystyka hydrologiczna estuaryjnych wód u polskiego wybrzeża. Prace PIHM, 105 (1972) 3-37.

[22] Majewski A., Charakterystyka hydrologiczna Zatoki Pomorskiej, Warszawa 1974.

[23] Mikulski Z., , Udziat wód rzecznych w stosunkach hydrologicznych Zalewu Szczecińskiego. Biul. PIHM, 5 (1960) 1-23.

[24] Mikulski Z., Wody śródlądowe w strefie brzegowej południowego Bałtyku. Biul. PIHM. 1970.

[25] Młodzińska Z., Zawartość tlenu. W: Majewski A. (red.), Zalew Szczeciński. Warszawa, (1980) 223-230.

[26] Młodzińska Z., b, Hydrochemia. W: Majewski A. (red.), Zalew Szczeciński. Warszawa, (1980) 248-277.

[27] Port Świnoujście. Urząd Morski w Szczecinie, 2008.

[28] Port w Świnoujściu - nabrzeża. Zarząd Morskich Portów Szczecin i Świnoujście SA. 2009

[29] Ryszard Kotla, Z dziejów szczecińskiego portu. „Magazyn Portowy”. 1/2007, s. 32. 